\title{
NEVADA BIRD RECORDS COMMITTEE REPORT FOR 2014
}

MARTIN MEYERS, Secretary, Nevada Bird Records Committee, c/o Great Basin Bird Observatory, 1755 E. Plumb Lane \#256, Reno, Nevada 89502;

NevadaBirdRecords@gbbo.org

ABSTRACT: In 2014, the Nevada Bird Records Committee (NBRC) reviewed 96 reports covering the period 1 December 1929-19 September 2014 and endorsed 89 of them. There were no changes to the Nevada list or the Nevada review list in 2014. In this year, however, the NBRC endorsed records of five species that had been on the state list without specific records previously endorsed: the Least StormPetrel (Oceanodroma microsoma), Wood Stork (Mycteria americana), Magnificent Frigatebird (Fregata magnificens), Snowy Owl (Bubo scandiacus), and Tropical Kingbird (Tyrannus melancholicus). Nevada's first successful nesting of the Common Black Hawk (Buteogallus anthracinus) was documented. The continuing increase in the Neotropic Cormorant (Phalacrocorax brasilianus) in the southwestern U.S. is reflected in Nevada, with the number of NBRC-endorsed records rising from two to seven in 2014.

The NBRC began 2014 with 55 reports pending review. During 2014, we added 73 reports to the pending queue. The committee completed reviews of 96 reports during the year, leaving 27 in the pending queue, the difference of five resulting from reports believed to represent multiple occurrences of the same individual and reports withdrawn prior to review. Since the founding of the NBRC in 1994, 1098 reports have been reviewed, of which 1005 (91.5\%) have been endorsed.

At its founding in 1994, the committee decided not to review any sightings prior to that year but reversed that decision several years later. Fortunately, founding secretary James Cressman and his wife Marian Cressman continued to accumulate documentation for "pre-committee" reports. One of the committee's long-term goals is to organize and review as many of those reports as possible, along with early documentation from other sources. The committee began reviewing pre-committee reports in 2007. Since that time, we have reviewed 125 and endorsed 112 . Of the 73 reports added to the pending queue in 2014, 23 preceded the committee's founding.

Of the 96 reports reviewed by the committee in 2014, 89 were endorsed. Of those, 81 were supported by photographs. Six were also supported by video recordings and four by audio recordings. Two were supported by specimens. Eight records were endorsed entirely on the basis of written descriptions (and, in one case, a sketch). None of the seven reports not endorsed was supported by a photograph, video recording, audio recording, or specimen.

The NBRC has six voting members and a nonvoting secretary. In 2014, the committee's voting members were Aaron Ambos, Carl Lundblad, Greg Scyphers, Dennis Serdehely, Jeanne Tinsman, and Will Richardson, and the position of secretary continued to be held by Martin Meyers.

The NBRC's website at www.gbbo.org/nbrc contains a statement of purpose, links to a downloadable submission form, the committee's bylaws, the Nevada state checklist, the state review list, and answers to frequently 
asked questions. There is a link to a list of all submissions to the NBRC, with the status of each with respect to endorsement and, if available, a photograph. All previous NBRC reports are available through the website as PDFs. NBRC reports through 2007 (1994-1996, 1997, 1998, 1999, 2000, 2004, 2005, and 2007) appeared in Great Basin Birds, published by the Great Basin Bird Observatory. Beginning with the 2011 report, annual reports appear in Western Birds. Reports for 2008 through 2010 are available only on the NBRC website.

\section{REVISIONS TO THE NEVADA STATE LIST AND NEVADA REVIEW LIST}

No species were added to or removed from the Nevada list during the period covered by this report. At the end of 2014, the Nevada list remains at 492. The committee uses the term "establishing record" to designate the first NBRC-endorsed record of a species that was already on the state list. Early in its history, the NBRC adopted an existing checklist (Titus 1996) based on numerous sources that constituted the most reliable information available at the time. At the end of 2013, there were 20 species on the list without an endorsed record. During 2014, the committee reviewed and endorsed records of five of these species, Records of four, the Least Storm-Petrel (Oceanodroma microsoma), Wood Stork (Mycteria americana), Magnificent Frigatebird (Fregata magnificens), and Snowy Owl (Bubo scandiacus), were endorsed on the basis of occurrences pre-dating the formation of the NBRC, the fifth, the Tropical Kingbird (Tyrannus melancholicus) on the basis of an occurrence in 2014. The committee continues to pursue documentation of the remaining 15 species. After all sources of documentation available to us have been exhausted, we will reevaluate the status of those remaining species.

No species were added to or removed from the Nevada review list in 2014. There are currently 156 species on the Nevada review list, of which five are exempt from review in some limited geographic area. In addition, two subspecies are currently on the review list: the Mexican Mallard (Anas platyrhynchos diazi) and the Eurasian Green-winged Teal (A. crecca crecca). The committee has endorsed four records of $A$. c. crecca. The committee placed A. p. diazi on the review list in an effort to accumulate data on its occurrence, but we have not, as yet, reviewed any of the reports and have decided to wait to do so until there is more clarity on its taxonomic status and identification criteria.

\section{SPECIES ACCOUNTS}

Each species account is introduced with a header in the following format: English name, scientific name, and, in parentheses, the total number of endorsed records of the species (including those endorsed in this report), followed by the number of records endorsed in this year's report. An asterisk preceding the species' name signifies that the species is no longer on the Nevada review list. Two asterisks after the total of records denote that the number of records refers to a restricted review period, usually signifying that the species is no longer on the review list, has been added to the review 
list because of a perceived drop in population, or is exempt from review in some locations. Note that one record can include multiple birds.

After the heading for each species comes each report of that species reviewed in 2014, in the following format: NBRC report number, date or range of dates of observations submitted to the NBRC, and location (county in parentheses). If the report involved multiple birds, the number follows the county designation.

For endorsed records: the name of each submitter, followed by "(P)," "(V)," or "(A)" if he or she provided a photo, video, or audio recording, respectively. If the initial finder or finders sent documentation to the NBRC, those names are listed first, followed by a semicolon. A pound sign (\#) indicates a specimen record; this is followed by the specimen's catalog number. In the case of a specimen, a "(P)" indicates that the specimen was photographed and that the photograph(s) are included in the documentation. The photographer in such cases, typically a representative of the committee or the housing institution, is not credited in the account.

If there are multiple observations of the species, they are ordered by date of first sighting. Any discussion of the species in general, not specific to an observation, concludes the account.

The museum collections housing specimens cited in this report are the Donald R. Dickey Bird and Mammal Collection at the University of California, Los Angeles (UCLA), and the University of Nevada, Reno Museum of Natural History (UNMB; formerly the University of Nevada Department of Biology Museum).

BRANT Branta bernicla (6, 2). 2013-067, Henderson Bird Viewing Preserve (Clark), 14 Jun 2013. R. Michal (P), D. DesMarais (P), T. Almond (P); originally found by C. Nycek.

2013-079, Soda Lake, Fallon (Churchill), 6 Aug-14 Sep 2013, four birds. M. Meyers (P); M. Andrews, G. Scyphers (P; Figure 1), K. Drozd (P). These geese were in extremely worn condition, which mitigated against their being aged with certainty (Chris Nicolai, U.S. Fish and Wildlife Service, pers. comm.).

BLACK SCOTER Melanitta americana (7, 1). 2013-016, Boulder Beach, Lake Mead National Recreation Area (NRA) (Clark), 5 Jan-2 Feb 2013. A. Lee (P); T. Almond (P). Female-like plumage.

RED-THROATED LOON Gavia stellata (8, 1). 2013-113, Las Vegas Bay and Government Wash, Lake Mead NRA (Clark), 7 Dec 2013-1 Mar 2014. Two immatures. A. Lee (P); M. Meyers, S. Burrell, C. Bullock (P), T. Hyde (P, V). The committee decided that the observation on 1 March likely represented one of the two birds seen on 7 and 19 December and combined the two reports into a single record.

YELLOW-BILLED LOON Gavia adamsii (7, 1). 2014-007, Sparks Marina (Washoe), 27 Dec 2013. T. Lenz (P, V). One juvenile found five years to the day after Lenz found another (2008-114) at the same location. The one in 2008 remained for much of that winter but that in 2013 was present for only one day.

LEAST STORM-PETREL Oceanodroma microsoma (2, 2). 2014-003, Lake Mojave, Lake Mead NRA (Clark), 12 Sep 1976. Two birds. W. Prange. Establishing record.

2014-004, Lake Mojave, Lake Mead NRA (Clark), 17 Sep 1976. C. S. Lawson (Lawson 1977).

These Least Storm-Petrels reached Nevada in the wake of hurricane Kathleen, which moved northeast from the Pacific Ocean, across Baja California and up the 


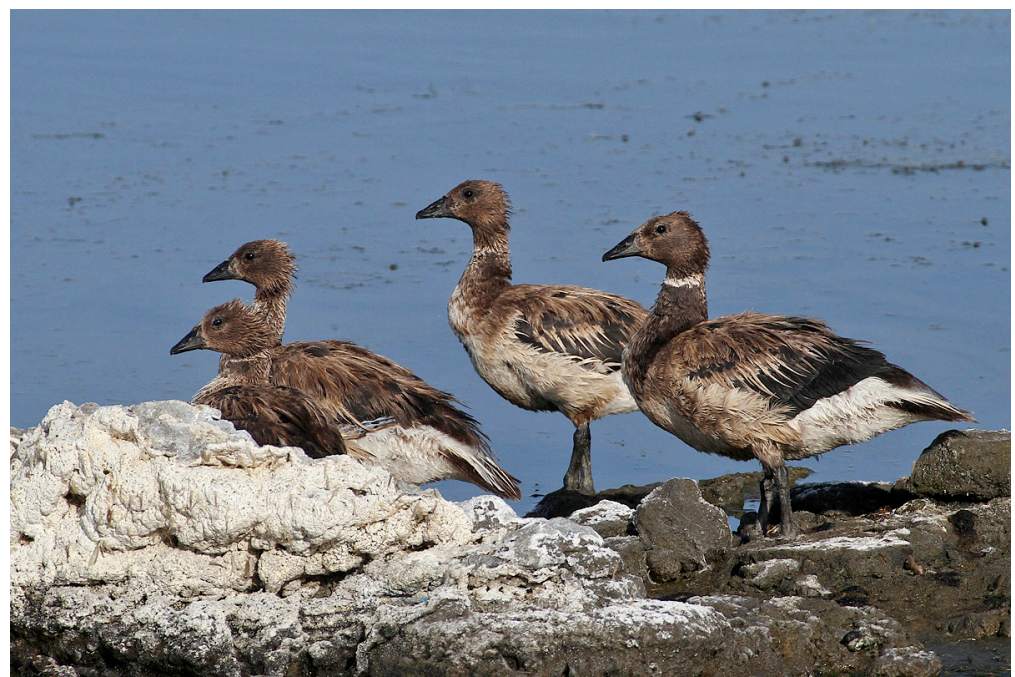

Figure 1. This group of heavily worn Brant lingered at Big Soda Lake, Churchill Co., from 6 Aug to 14 September 2013, providing viewing opportunities for many northern Nevada birders.

Photo by Greg Scyphers

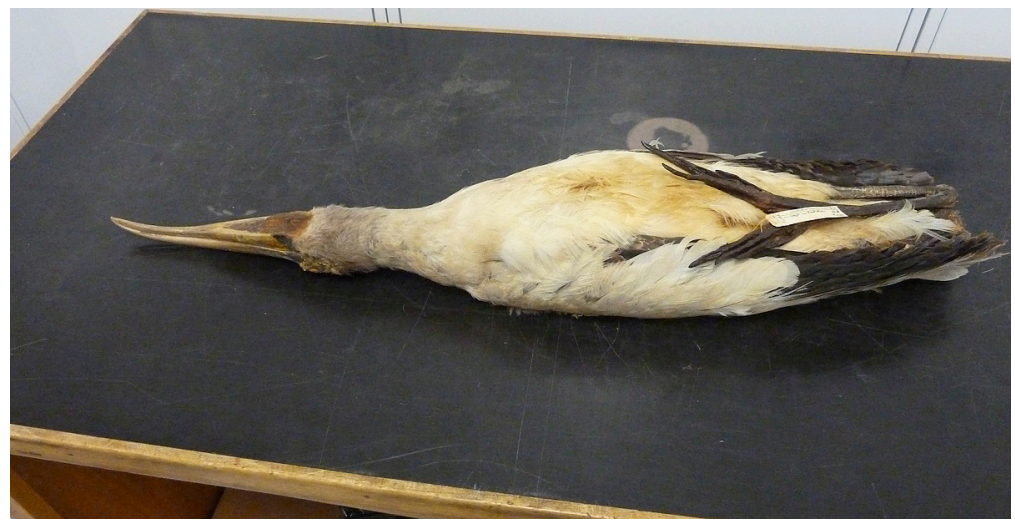

Figure 2. The NBRC has been working hard over the past few years attempting to find and review documentation for species on its review list for which it had no endorsed records. Part of that effort involves searching for museum specimens. This Wood Stork, collected at St. Thomas, Clark Co., 22 September 1930 by A. J. van Rossem, is preserved in the Donald R. Dickey Bird and Mammal Collection, University of California, Los Angeles. 
Colorado River valley on 10 September 1976 . Simultaneously, as many as 1000 also reached the Salton Sea, Imperial County, California (Patten et al. 2003).

WOOD STORK Mycteria americana $(1,1)$. 2014-006, St. Thomas, Lake Mead NRA (Clark), 22 Sep 1930. A. J. van Rossem (P, \#UCLA 31185; Figure 2). Juvenile. Establishing record. The location, St. Thomas, was inundated when Lake Mead was filled in the 1930s, but the recent drought has allowed the ghost town to emerge from the Overton Arm of the lake (www.nps.gov/lake/naturescience/st-thomas-nevada. htm). Linsdale (1936) listed six records for Nevada, dating back to 1871, including two preserved specimens but not this one. He reported that W. H. Burt had seen a flock of 25 circling high in the air just east of St. Thomas the day before van Rossem collected the specimen. Alcorn (1988) summarized other sightings, mostly from southern Nevada but including a few from central and northern locations as well. He quoted C. S. Lawson's assessment, in 1976, that the Wood Stork was "an occasional to rare summer visitant." Since the 1980s, however, there have been no further reports, paralleling the species' decline in the southwestern U.S. as a whole (e.g., Patten et al. 2003).

MAGNIFICENT FRIGATEBIRD Fregata magnificens (1, 1). 2014-041, Davis Dam, Lake Mead NRA (Clark), 17 Sep 1976 (following hurricane Kathleen). C. S. Lawson (P). Establishing record. The poor reproduction of the photo in Lawson (1977) was supplemented with a copy of the original slide.

2014-042, Las Vegas (Clark), 18 Nov 1983. NOT ENDORSED. A letter to the editor in the Las Vegas Review Journal (22 November 1983) reported this sighting. The brief description convinced the committee that a frigatebird was seen, but was insufficient to identify the species.

BROWN BOOBY Sula leucogaster $(2,1)$. 2014-008, Cottonwood Cove, Lake Mojave, Lake Mead NRA (Clark), 16-17 Feb 2014. J. Tinsman (P; Figure 3); G. Scyphers (P). David Vander Pluym provided the committee with photos of a Brown Booby that spent much of winter 2013-2014 some $113 \mathrm{~km}$ to the south at Lake Havasu in Arizona. Comparisons of plumage showed that the Nevada bird was the same individual. Vander Pluym also wrote, "I also received an eBird report from the morning of the 16th of a Brown Booby flying north along the Colorado River in Bullhead City. Plenty of time for it to reach Cottonwood Cove by the afternoon." The only previous record for Nevada is of two at Las Vegas Bay, Lake Mead, on 27 August 1971 (Lawson 1973a).

NEOTROPIC CORMORANT Phalacrocorax brasilianus (7, 5). 2013-085, Davis Dam (Clark), 21 Aug 2013. M. Meyers (P). This juvenile was photographed sitting on the Arizona side but was observed flying into Nevada for a brief swim.

2013-100R, Floyd Lamb Park (Clark), 28 Sep 2013-13 Jul 2014. M. Meyers (P; this issue's inside back cover); J. Icenogle (P), J. Tinsman (P). Found simultaneously by Meyers and Scyphers on the day of the NBRC's biennial meeting. The bird's location and age (adult) convinced the committee that it was the same individual present during winter 2012-2013 (NBRC 2012-056).

2014-011, Floyd Lamb Park (Clark), 4-25 May 2014. A. Lee (P), D. Vogt (P). Juvenile. A report via www.ebird.org for 27 April 2014, not submitted to the NBRC, is almost certainly of the same bird.

2014-034, Henderson Bird Viewing Preserve (Clark), 20 Jun-25 Jul 2014. C. Nycek (P); R. Michal, T. Hyde (P), E. Hough (P). Juvenile.

2014-051, Sunset Park, Las Vegas (Clark), 9 Aug 2014. J. Boone (P). Adult.

Substantial increases in sightings of this species in southeastern California, western Arizona, and southwestern Utah (and north along the Wasatch front) were described in last year's NBRC report (Meyers 2015).

BROWN PELICAN Pelecanus occidentalis $(11,4)$. 2014-039, Las Vegas Bay, Lake Mead NRA (Clark), 13-30 Sep 1971. C. S. Lawson (P). Immature. 


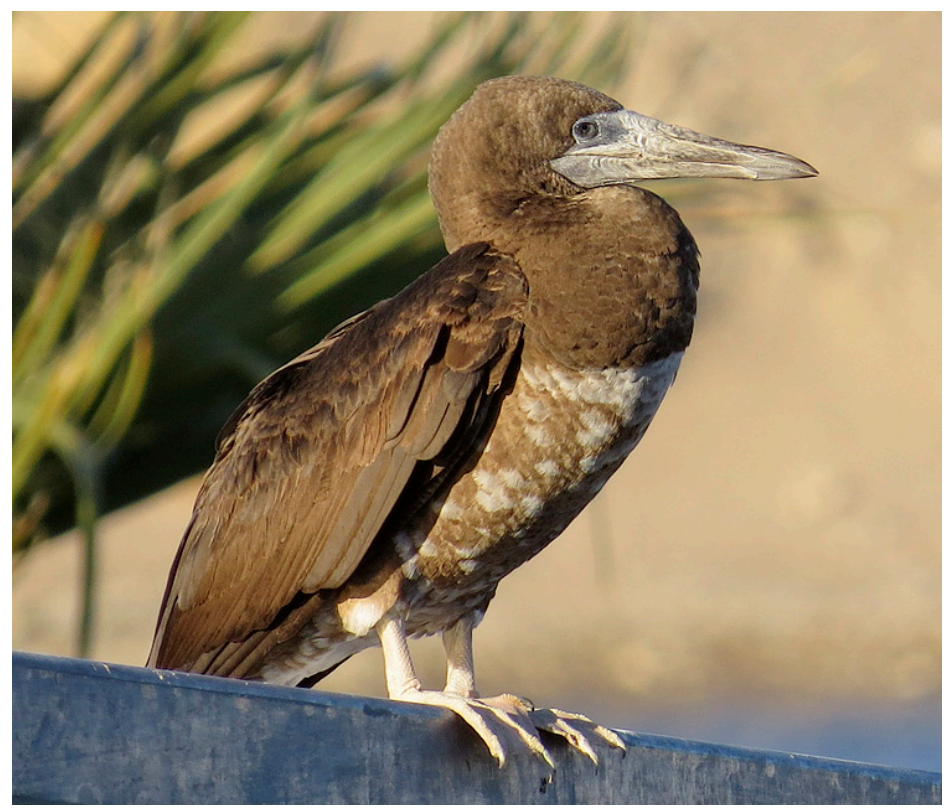

Figure 3. On the basis of timing of observations and comparison of photos, this immature Brown Booby at Lake Mojave, Clark Co., 16-February 2014 is presumed to be the same bird that spent much of the winter at Lake Havasu, Arizona. It represents Nevada's second record of the Brown Booby, more than 42 years after the first.

Photo by Jeanne Tinsman

2013-088, Las Vegas Bay, Lake Mead NRA (Clark), 28 Nov-19 Dec 1992, two birds. S. Finnegan, C. Titus (P). One adult, one immature.

2013-081, Laughlin (Clark), 5 Aug 2013. K. and N. Finklestein (P). This immatureplumaged bird spent the day riding a shuttle boat back and forth across the Colorado River between Laughlin and the Arizona side.

2013-080, Las Vegas Bay, Lake Mead NRA (Clark), 7-20 Aug 2013. A. Lee (P); M. Meyers (P). Immature.

LITTLE BLUE HERON Egretta caerulea (4, 2). 2014-020, Las Vegas Bay, Lake Mead NRA (Clark), 17 Jun 1983. M. Kasprzyk. Adult.

2014-021, Las Vegas Bay, Lake Mead NRA (Clark), 23 Aug 1990. NOT ENDORSED.

2014-018, Floyd Lamb Park (Clark), 28-30 May 2014. G. Scyphers (P; Figure 4); D. Vogt (P), M. Meyers. Adult. Reported via eBird on 1 June and via the Nevada Birds Listserv through 21 June.

The four Nevada records of the Little Blue Heron are for spring (21 April-17 June), consistent with sightings from Arizona, where the species is a "casual spring and summer visitor to southern Arizona" (www.azfo.org/gallery). In contrast, all three Nevada records of the Reddish Egret are for summer (27 July-19 September), corresponding closely to the seven California desert records through 2001, which span 28 July-29 September (Hamilton et al. 2007). However, seven of the nine 
Arizona records of the Reddish Egret are from fall and winter (http://abc.azfo.org/ ABCVote/_ABCReports_Public_View_list.aspx).

REDDISH EGRET Egretta rufescens (3, 1). 2014-046, Las Vegas Bay, Boulder Beach, and Boulder Harbor, Lake Mead NRA (Clark), 27 Jul-19 Sep 2014. T. Hyde $(\mathrm{P})$, Eric Hough (P); G. S. Clemson (P), M. Meyers (P). Reported via the Nevada Birds Listserv until 29 September. This cooperative, long-staying immature was the first of this species to be documented in Nevada since 2004 (Meyers 2010).

*WHITE-TAILED KITE Elanus leucurus (18**, 1). 2014-040, Upper Las Vegas Wash (Clark), 14 Mar-1 Apr 1994. M. Cressman. This species was removed from the state review list in 2013, but reports preceding that date continue to be reviewed.

COMMON BLACK HAWK Buteogallus anthracinus (11, 2). 2013-087, Meadow Valley Wash (Lincoln), 26 Aug-1 Sep 2013, two birds. A. Ambos (P); R. Lowry.

2014-050, Meadow Valley Wash (Lincoln), 18-25 Jun 2014, three birds. M. Buschow $(\mathrm{P}, \mathrm{V})$. Breeding had been suspected for several years. Pairs had been seen, some displaying together. Buschow discovered the first nest on 18 June. In her words, "First bird alerted me to its presence by pooping on me." On a return visit on 25 June, she photographed a downy chick in the nest (Figure 5).

HARRIS'S HAWK Parabuteo unicinctus (8, 1). 2013-103, Las Vegas (Clark), 19 Oct 2013-17 Jan 2014. N. McDonal; C. Grant (P). Two reports documented a Harris's Hawk in the same general vicinity in Las Vegas. The committee voted to consider both as representing the same individual and suspected it was a wanderer

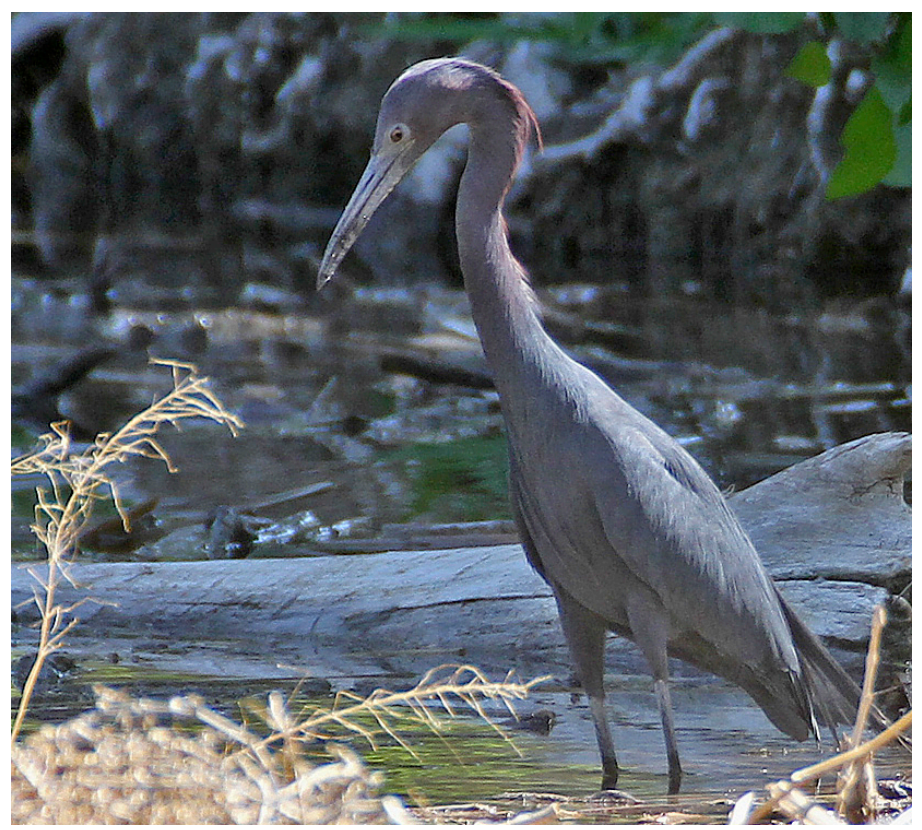

Figure 4. Documentation for Nevada's fourth endorsed record of the Little Blue Heron covers the dates 28-30 May 2014, but reports to www.eBird.org and the Nevada Birds Listserv indicate that the bird may have been present for at least another three weeks. All four records are of adults in Nevada's southernmost county, Clark. 


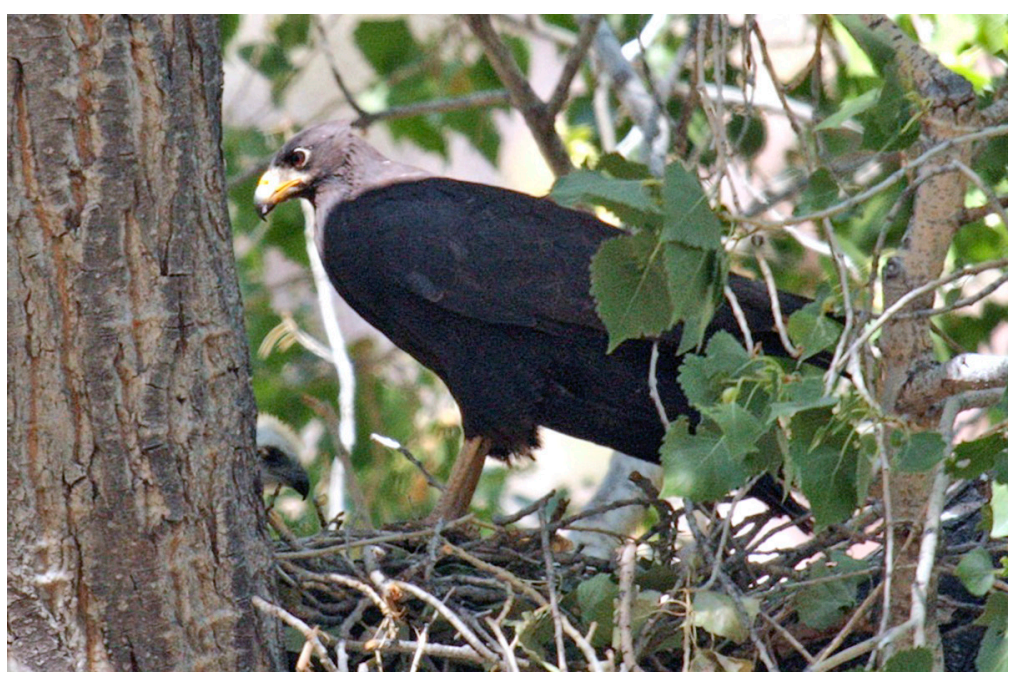

Figure 5. Confirmation of the first successful breeding of the Common Black Hawk in Nevada, in Meadow Valley Wash, Lincoln Co., came on 25 June 2014 when Marissa Buschow captured this image of the downy head of a chick in the nest, attended by one of the parents.

Photo by Marissa Buschow

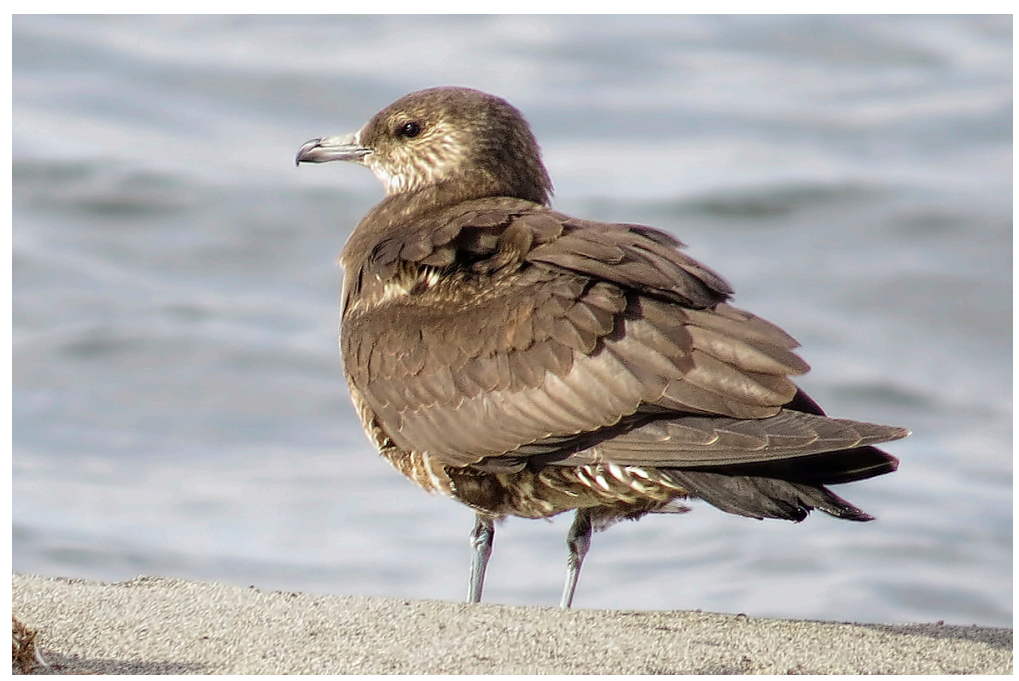

Figure 6. Most of Nevada's Parasitic Jaegers have been seen only in flight, occasionally perched or swimming at a distance. But this subadult photographed at close range at Pyramid Lake, Washoe Co., 3-7 September 2013 allowed superb documentation of features such as the shape and pattern of the bill and the characteristic warm tones to the plumage.

Photo by Dennis Serdehely 
from the small group (NBRC 2011-105) nesting in nearby Boulder City from 2011 through at least early 2013 (Meyers 2014). Out-of-range Harris's Hawks sometimes pair, establish groups, and breed for a number of years but typically then die out or move on, as has occurred on several occasions in southeastern California (Patten and Erickson 2000, Unitt 2004).

RUDDY TURNSTONE Arenaria interpres $(5,1)$. 2013-083, south end of Pyramid Lake (Washoe), 17-18 Aug 2013. R. Lowry (P); M. Meyers (P). Juvenile, for which the date is a bit early (J. L.Dunn in litt.)

RUFF Calidris pugnax (4, 1). 2013-049, Henderson Bird Viewing Preserve (Clark), 26 Sep 1992. M. Cressman (P). This juvenile represents Nevada's first record of the Ruff.

BUFF-BREASTED SANDPIPER Calidris subruficollis (0, 0). 2014-031, south end of Pyramid Lake (Washoe), 31 Aug 1994. NOT ENDORSED. This is one of the 15 species listed for Nevada by Titus (1996) for which the NBRC has endorsed no records.

RED PHALAROPE Phalaropus fulicarius $(13,4)$. 2014-036, Upper Las Vegas Wash (Clark), 5 Jun 1971, at least four birds photographed. C. S. Lawson (P).

2014-037, Upper Las Vegas Wash (Clark), 25-26 Jul 1972. C. S. Lawson (P, \#UNMB 1748). Lawson (1973b) wrote, "On 26 July 1972 I collected a Red Phalarope ... from a flock of about 250 phalaropes. The flock consisted of 4 or 5 Red Phalaropes in winter plumage, 225 Wilson's Phalaropes..., and 25 Northern Phalaropes." The preceding day, Lawson had photographed a male in breeding plumage, the same plumage as the specimen (unpublished notes and slide on file). Because of the inconsistencies regarding the number of birds and their plumage, the committee endorsed only a single individual.

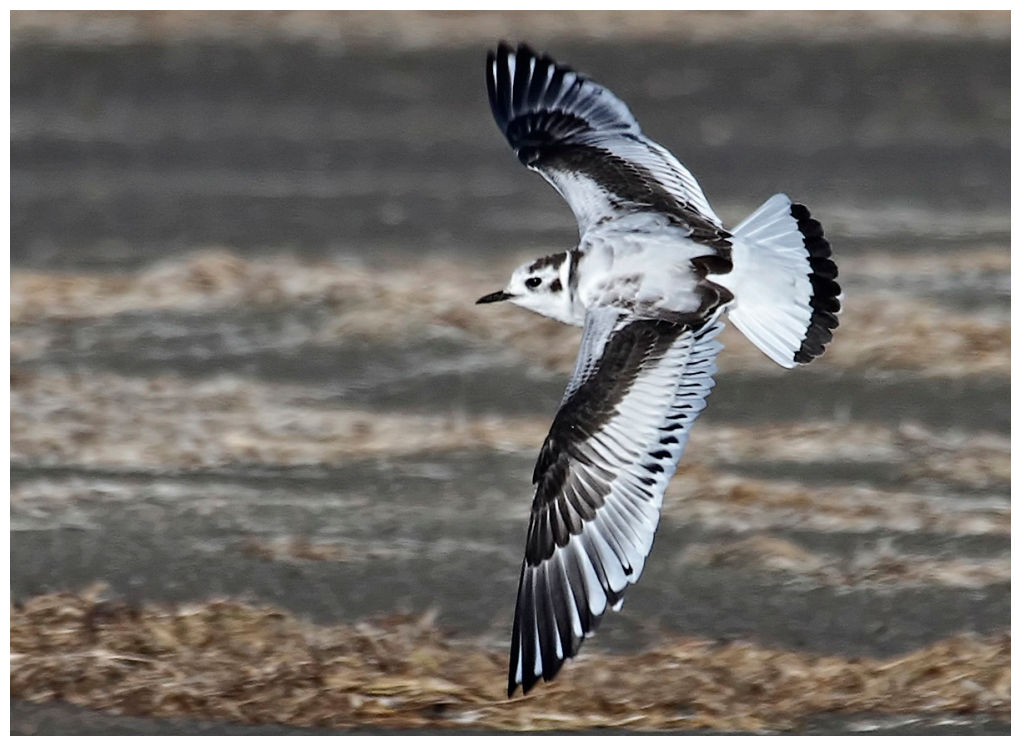

Figure 7. This first-cycle Little Gull at Pyramid Lake, Washoe Co., represents a second record for Nevada. It remained for only one day, 30 October 2013.

Photo by Martin Meyers 
2013-117, Key Pittman Wildlife Management Area (WMA) (Lincoln), 3 Aug 2013. G. Scyphers (P).

2014-048, private property at Silver Peak (Esmeralda), 31 Jul 2014. G. Scyphers (P).

PARASITIC JAEGER Stercorarius parasiticus (8, 2). 2013-091, south end of Pyramid Lake (Washoe), 3-7 Sep 2013, two birds. D. Serdehely (P; Figure 6); G. and P. Nelson (P), R. Lowry (P), M. Meyers (P), M. Andrews, K. Drozd (P), F. Welden (P). 2013-101, south end of Pyramid Lake (Washoe), 6 Oct 2013. D. Serdehely (P).

In contrast to those for the Long-tailed Jaeger, none of the records the NBRC has endorsed of the Parasitic Jaeger are of adults.

LONG-TAILED JAEGER Stercorarius longicaudus (12, 2). 2013-074, Onion Valley Reservoir (Humboldt), 9 Jul 2013. J. Ballard (P).

2014-009, Wild Horse Reservoir (Elko), 30 Aug 2013. S. Barnes.

Both of these records were of adults, as are half of Nevada's 12 records. Of course, adults are much easier to identify so it is probably unrealistic to suggest that these numbers translate to the actual ratio.

BLACK-LEGGED KITTIWAKE Rissa tridactyla (7, 1). 2013-089, Las Vegas Bay, Lake Mead NRA (Clark), 28 Nov-19 Dec 1992. S. Finnegan; C. Titus (P). This firstcycle gull represents Nevada's second earliest record of this species.

LITTLE GULL Hydrocoloeus minutus (2, 1). 2013-106, south end of Pyramid Lake (Washoe), 30 Oct 2013. M. Meyers (P; Figure 7); G. Scyphers (P), R. Lowry (P). First cycle. The only Little Gull previously endorsed (2007-149) was also in its first cycle, at Key Pittman WMA (Lincoln County) 24-26 November 2007 (Meyers 2010).

HEERMANN'S GULL Larus heermanni (12, 2). 2013-094, Virginia Lake, Reno (Washoe), 14 Apr 2004. J. Thompson (P); originally found by Fred Petersen. Adult in alternate plumage.

2013-102, south end of Pyramid Lake (Washoe), 6 Oct 2013. R. Lowry (P); D. Serdehely (P). Second or third cycle.

Nine of Nevada's 12 records have been of adults. Five of the 12 were found in October, four in April, two in May, and one in June

*MEW GULL Larus canus (11**, 3). 2013-058, Las Vegas Bay, Lake Mead NRA (Clark), 9 Jan-27 Feb 1972. C. S. Lawson (P). First cycle.

2013-061, Virginia Lake, Reno (Washoe), 29 Mar 1988. P. E. Lehman (P). Very worn plumage of the first cycle.

2013-060, Henderson Bird Viewing Preserve (Clark), 28 Jan-7 Feb 1993. M. Cressman (P). Adult.

2013-059, Henderson Bird Viewing Preserve (Clark), 10 Jan 2000. NOT ENDORSED.

WESTERN GULL Larus occidentalis (8, 1). 2013-109, Lake Mojave, Lake Mead NRA (Clark), 26 Oct 2013. T. Almond (P). First-cycle bird photographed in flight. Multiple photos revealed a thick, bulbous-ended, all-dark bill with a prominent gonydeal angle. The outer primaries appeared entirely black. One photo showed most of upperwing, which lacked an obvious pale panel in the inner primaries. These features, combined with the bird's overall shape and broad wings, convinced all but one member of the committee of the identification. Nevada records of the Western Gull come from three counties, Washoe (3), Mineral (2), and Clark (3). Inland records of this species in California, particularly at the Salton Sea, have increased significantly in recent years. For example, McCaskie and Garrett (2014) reported, "up to 20 Western Gulls at [the sea's north end] through the period (March through May 2013) illustrate how numerous this gull has become on the Salton Sea."

LESSER BLACK-BACKED GULL Larus fuscus (16, 4). 2013-112, Hemenway Harbor and Las Vegas Bay, Lake Mead NRA (Clark), 7-28 Dec 2013. A. Lee (P); D. Vogt (P), R. Lowry. First-cycle. 
2013-114R, Las Vegas Bay, Lake Mead NRA (Clark), 28 Dec 2013. A. Lee (P); D. Vogt $(\mathrm{P}), \mathrm{R}$. Lowry $(\mathrm{P})$. This adult is considered to represent a return of the adult observed at the same location in January 2012 (2012-004).

2014-001, Sparks Marina (Washoe), 6 Jan 2014. G. Scyphers (P); M. Meyers (P). First cycle.

2014-013, Sparks Marina (Washoe), 16 Apr 2014. G. Scyphers (P). Since Sparks Marina, is checked regularly, more than three months had passed between the two sightings, and the birds differed in plumage and structure, the committee concluded that the bird seen in January had not remained there until April.

GLAUCOUS GULL Larus hyperboreus (15, 4). 2014-032, Boulder Beach, Lake Mead NRA (Clark), 30 Nov-16 Dec 1972. C. S. Lawson (P). A typed summary of the Henderson Christmas Bird Count commented that the bird had been present "since November 20," which contradicts Lawson's report and Lawson (1973b), which specified the first sighting as 30 November. This first-cycle bird represents the first Nevada record of the Glaucous Gull.

2013-095, Lockwood (Storey), 6 Jan 1991. J. Thompson (P). First cycle.

2013-096, Lockwood (Storey), 10 Jan 1991. J. Thompson (P). Adult.

2014-002, Las Vegas Bay, Lake Mead NRA (Clark), 11-23 Jan 2014. A. Lee (P);

D. Ghiglieri (P; Figure 8). Adult.

SNOWY OWL Bubo scandiacus (1, 1). 2014-005, Indian Springs (Clark), 1 Dec 1929. A. J. van Rossem (P, \#UCLA 31263, Linsdale 1936). Establishing record. There are a few anecdotal reports of the Snowy Owl in Nevada, but none contain enough documentation to allow committee review. The winters of 1926-1927 and 1930-1931 saw substantial Snowy Owl invasions into the northern U.S., but that of 1929-1930 did not (Gross 1931).

TROPICAL KINGBIRD Tyrannus melancholicus (1, 1). 2014-026, Laughlin (Clark), 15 May 1980. NOT ENDORSED.

2014-025, Pahranagat National Wildlife Refuge (NWR) (Lincoln), 7 Nov 1982. NOT ENDORSED.

2014-024, Miller's Rest Stop (Esmeralda), 17 Jun 2014. G. Scyphers (P, V), M. Meyers (P, V; Figure 9). Establishing record.

The first two reports are of Tropical/Couch's (T. couchii) Kingbirds, but their documentation was insufficient for species identification. Record 2014-024, on the other hand, was supported with extensive recordings of vocalizations, as well as

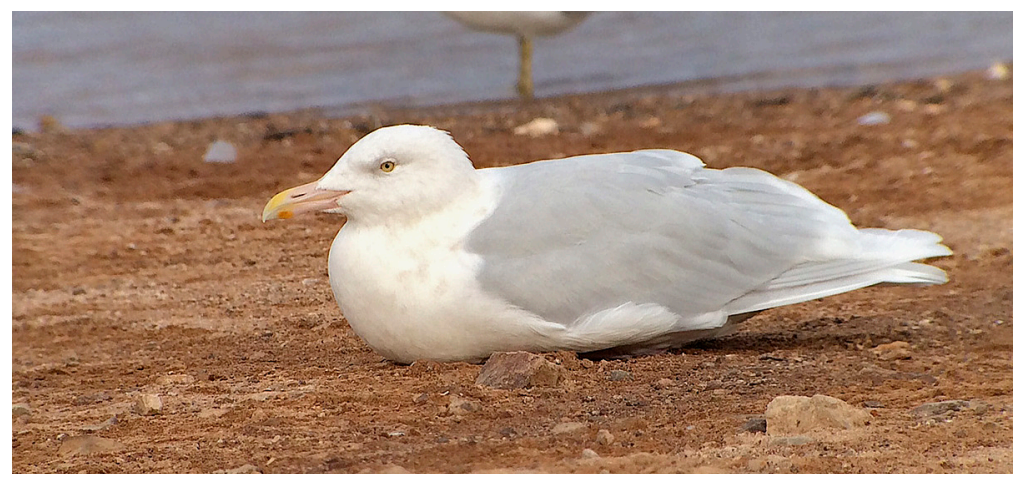

Figure 8. Of Nevada's 15 endorsed records of the Glaucous Gull, three have been of adults, like this individual at Las Vegas Bay, Lake Mead, 11-23 January 2014. 


\section{NEVADA BIRD RECORDS COMMITTEE REPORT FOR 2014}

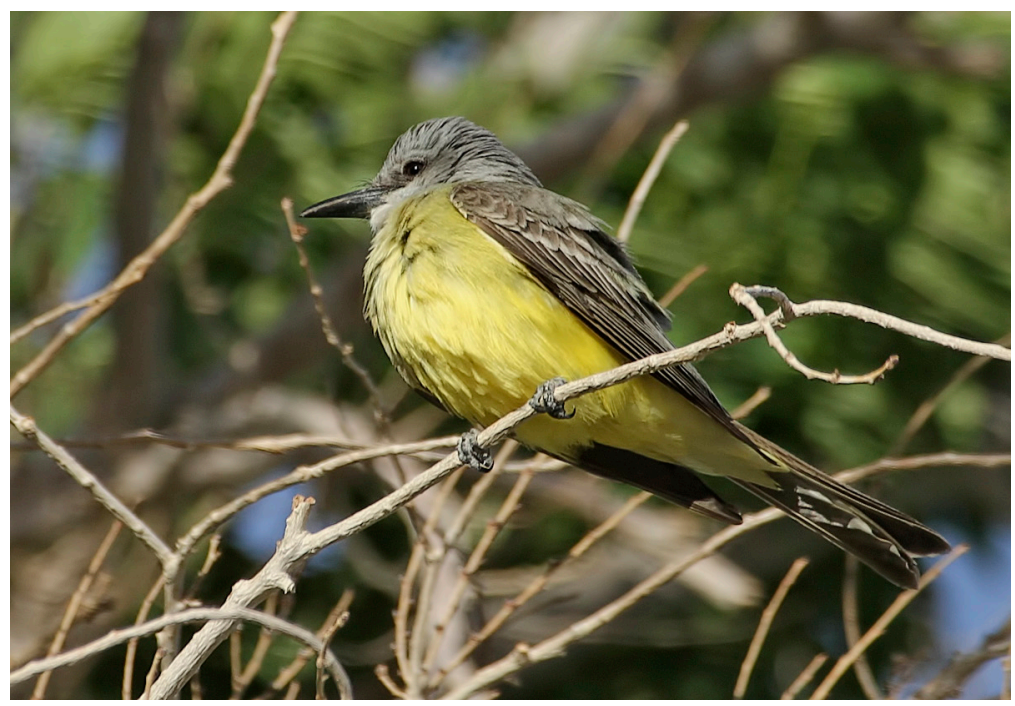

Figure 9. This Tropical Kingbird at Miller's Rest Stop, Esmeralda Co., 17 June 2014 is the first to be endorsed by the NBRC. Documentation for earlier sightings did not eliminate Couch's Kingbird. Fortunately, this bird was video-recorded vocalizing repeatedly, confirming the identification.

Photo by Martin Meyers

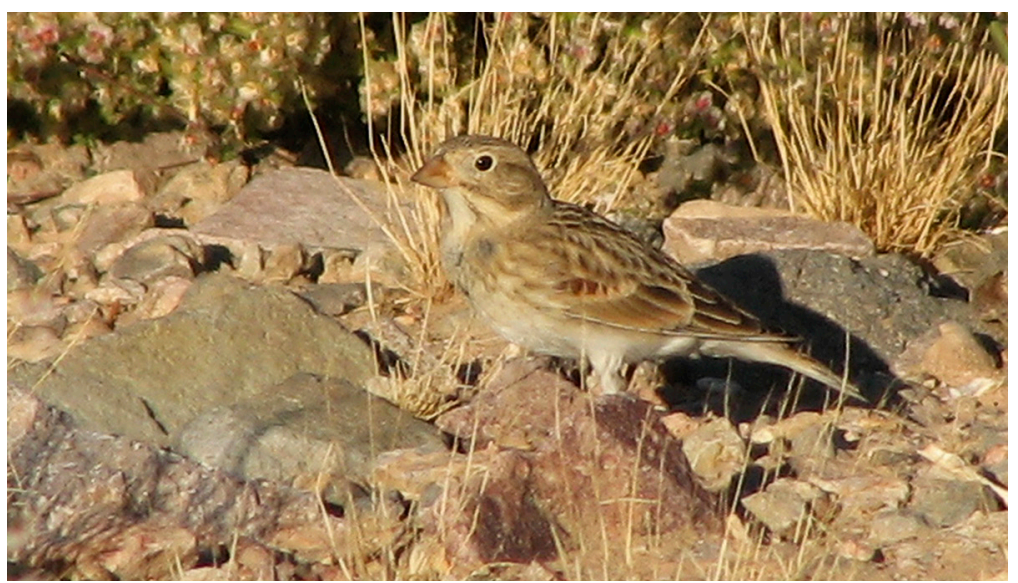

Figure 10. The Lapland (Calcarius lapponicus) and Chestnut-collared (C. ornatus) Longspurs have proven to be fairly regular visitors to Nevada in fall and winter, and both species have been removed from the Nevada review list. But McCown's is encountered considerably less frequently. This male found near the shoreline of Lake Mead on 26 October 2013 was the fifth to be endorsed by the NBRC. Smith's Longspur (C. pictus) has been satisfactorily documented twice.

Photo by Andrew Lee 
photos permitting assessment of the wing formula, identifying this Tropical Kingbird convincingly. This species is considered "Rare but regular along the West Coast to BC" by Dunn and Alderfer (2011) and breeds as close to Nevada as the lower Colorado River Valley (http://azfo.org/seasonalReports/SeasonalReportSummer2011.html). The Tropical would seem much more likely to occur in Nevada than Couch's, but Couch's has been documented in both Arizona (Rosenberg et al. 2011) and California (Rottenborn and Morlan 2000); the 2015 NBRC report will discuss Nevada's first Couch's Kingbird, found in January 2015.

SCISSOR-TAILED FLYCATCHER Tyrannus forficatus (8, 1). 2014-023, Miller's Rest Stop (Esmeralda), 26 May 2014. R. Lowry (P).

YELLOW-THROATED VIREO Vireo flavifrons (6, 1). 2013-048, near Derby Dam (Washoe), 28 May-7 Aug 2013. G. Scyphers (P, A); M. Meyers (A), Z. Ormsby (A). This is the first record for northern Nevada.

PHILADELPHIA VIREO Vireo philadelphicus $(3,1)$. 2013-118, Dyer (Esmeralda), 26 May 2013. G. Scyphers (P, A). Nevada's first spring record. The two previous records are from Indian Springs (Clark), 23 September 1995, and Floyd Lamb Park (Clark), 19-23 October 2010 (Cressman et al. 1998, Meyers 2013). In California, only 11 of 116 records endorsed by the CBRC through 1998 are for spring (Hamilton et al. 2007).

RED-EYED VIREO Vireo olivaceus (11, 5). 2013-070, Las Vegas (Clark), 22 Jun 2013. J. Swift (P).

2013-093, Floyd Lamb Park (Clark), 10 Sep 2013. A. Lee (P).

2013-119, Bonham Ranch (Washoe), 11 Sep 2013. G. Scyphers (P).

2013-098, Corn Creek (Clark), 17 Sep 2013. J. Tinsman (P).

2014-017, Mogul (Washoe), 26 May 2014. J. Anderson (P).

In addition, a fifth record, of a Red-eyed Vireo sharing an active nest with a Warbling Vireo (V. gilvus) in a park in Reno (Washoe) in July 2013 was endorsed in 2015 (details in next year's report). Prior to 2013, no more than two Red-eyed Vireos were recorded in Nevada in any one year.

BLUE JAY Cyanocitta cristata (3, 1). 2014-028, Elko (Elko), 16 Oct-23 Dec 1989. L. Hoskins (P). Photographed at feeder.

PURPLE MARTIN Progne subis (12, 5). 2013-065, Dyer (Esmeralda), 24 May 2013, two birds. R. Lowry (P). Female-type plumage.

2013-115, Corn Creek (Clark), 24 May 2013. G. Scyphers (P). Adult female.

2013-082, Floyd Lamb Park (Clark), 15 Aug 2013. A. Lee (P). Female-type plumage.

2013-107, Corn Creek (Clark), 9 Sep 2013. J. Bailey (P). Female-type plumage. 2014-015, Corn Creek (Clark), 22 May 2014. A. Lee (P). Female-type plumage.

WINTER WREN Troglodytes hiemalis (3, 1). 2013-108, Pahranagat NWR (Lincoln), 13 Nov-27 Dec 2013. R. Fridell (P, A); M. Meyers (P, V, A), R. Lowry (P). This individual was found at the same location where Nevada's second Winter Wren (2011-092) was observed in November 2011 (Meyers 2014). This section of Pahranagat NWR has also seen several Pacific Wrens (T. pacificus) in November and December during the years of the two Winter Wren sightings as well as in 2012, when no Winter Wren was observed. The committee voted to consider 2013-108 an individual different from 2011-092.

VEERY Catharus fuscescens (3, 0). 2013-047, Corn Creek (Clark), 27-28 May 2013. NOT ENDORSED. Two written reports but no photos or audio/video recordings were submitted. The documentation was strong, but the committee decided that the difficulty of identification, particularly possible confusion with the Russet-backed Swainson's Thrush (C. ustulatus ustulatus), which is regular in Nevada in spring migration, argued against endorsement. 
*CHESTNUT-COLLARED LONGSPUR Calcarius ornatus (9**, 1). 2013-006, Key Pittman WMA (Lincoln), 23 Sep 2011. G. Scyphers (P); M, Meyers (P). At its biennial meeting the day after this sighting, the committee voted to remove the species from the review list. The nine records the NBRC has endorsed involve a total of 33 birds.

MCCOWN'S LONGSPUR Rhynchophanes mccownii (5, 1). 2013-104, Boulder Beach, Lake Mead NRA (Clark), 26 Oct 2013. A. Lee (P; Figure 10).

LOUISIANA WATERTHRUSH Parkesia motacilla (4, 2). 2014-044, Pahranagat NWR (Lincoln), 19 Jul 2014. A. Pellegrini (P). Mist-netted, banded, and released.

2014-049, Corn Creek (Clark), 4-5 Aug 2014. J. Bailey (P); D. Vogt (P), M. Swink (P).

These very early-season records fit with the pattern of fall migration in the species' regular range, where it is one of the earliest of all eastern wood-warblers (Dunn and Garrett 1997). In California, CBRC-endorsed fall records begin in early August (Hamilton et al. 2007).

RED-FACED WARBLER Cardellina rubrifrons (3, 1). 2013-071, Kyle Canyon area, Mt. Charleston (Clark), 29 Jun-3 Aug 2013. A. Lee (P; Figure 11). All three Nevada records are from Kyle Canyon in summer. In August 2007, a single individual (2007-094) was observed over two weeks (Meyers 2008). In 2009, a single individual (2009-075) was present 22 June-9 August (Meyers 2010), timing very similar to the 2013 record. In 1974, there were scattered reports at various locations in the Spring Mountains (which include Mt. Charleston), all in September (Alcorn 1988; records the NBRC has not reviewed). In California, all of the records endorsed by the CBRC through 2005 span the period 13 May-8 October (Hamilton et al. 2007, http:// www.californiabirds.org/cbrc_book/update.pdf).

PAINTED REDSTART Myioborus pictus $(11,4)$. 2014-035, Ft. Mojave (Clark), 25-27 Feb 1976. C. S. Lawson (P, \#UNMB 1803); V. Mowbray.

2013-041, Floyd Lamb Park (Clark), 6 Apr 2013. R. Bourgea (P).

2013-069, Kyle Canyon area, Mt. Charleston (Clark), 15 Jun 2013. N. Nye (P). 2014-012, Floyd Lamb Park (Clark), 5 May 2014. A. Lee (P).

Only the 1976 record (2014-035) is for winter. All others are from April (five records), May (two), and June (three). "Painted Redstarts summer casually in the mountains of southern California," while "fall and winter birds occur mainly along the southern coastal slope" (Hamilton et al. 2007). The species breeds in the Hualapai Mountains just south of Kingman, Arizona, less than 35 miles from the Nevada border (Corman and Wise-Gervais 2005).

GRASSHOPPER SPARROW Ammodramus savannarum (6, 1). 2013-099, Las Vegas Bay, Lake Mead NRA (Clark), 21 Sep 2013. R. Bailey (P); J. Streit. All six records the NBRC has endorsed are from late September through late October. A few $19^{\text {th }}$ century records, including one specimen of a juvenile, imply the Grasshopper Sparrow was a rare breeding species in northern Nevada at least formerly, and three reports from the breeding season are published in the Nevada breeding bird atlas (Floyd et al. 2007). Linsdale (1936) collected one specimen at the southern tip of Nevada along the Colorado River opposite Fort Mohave, Arizona, on 7 May 1934 (MVZ 64914). None of these records has yet been reviewed by the committee.

HEPATIC TANAGER Piranga flava $(2,1)$. 2014-043, Kyle Canyon area, Mt. Charleston, Spring Mountains (Clark), 4-24 Jul 2014. B. Murray (P; Figure 12); M. Swink (P), M. Meyers (P, V, A). Adult male. Murray reported that the male was accompanied by another tanager that might have been a female Hepatic, but she was unable to be certain. Meyers also reported that the male was briefly accompanied by a yellow tanager, but he could not confirm its identification. The only other record (2002-18) of the Hepatic Tanager the NBRC has endorsed, also of an adult male, is from Miller's Rest Stop, a desert migrant trap, 29 September 2002 (Cochran 2006). 
The species was first recorded from Nevada by Johnson (1965), who saw one in Hidden Forest Canyon, Sheep Range (Clark), on 7 June 1963, probably heard another higher in the canyon the following day, and reported that R. A. Fletcher collected one in the Clover Mountains (Lincoln) on 26 June 1963 (MVZ 150699; records not yet considered by the NBRC). On this basis, apparently, Austin and Bradley (1971) listed the Hepatic Tanager as a visitor in Clark County's woodlands and as a summer resident in its montane forests and C. S. Lawson (in Alcorn 1988) inferred it was "an uncommon to rare breeding species in the mountains of southern Nevada." By the time of publication of the Atlas of the Breeding Birds of Nevada (Floyd et al. 2007), "the conventional wisdom was that the species was present in these Vegas-area sky islands," leading to surprise at the lack of observations in the Spring Mountains from 1997 to 2000. In fact, the occurrence in 2014 represents the first specific published record of the Hepatic Tanager for the Spring Mountains.

NORTHERN CARDINAL Cardinalis cardinalis $(3,1)$. 2014-038, Las Vegas (Clark), 6 Jan-7 Mar 1975. C. S. Lawson (P). In his typed report to American Birds for winter 1974-1975 (with handwritten annotations), Lawson commented that this female was noted initially in the last week of December 1974. He first observed it 6 January, photographed it 7 January, and last observed it 7 March. All three Nevada records of the Northern Cardinal (two females, one male) have been from the Las Vegas area. None were conclusively identified to subspecies. In all cases, on the basis of proximity to the breeding range and no obvious evidence of captivity in plumage or structure, the committee decided that the birds were likely of natural origin. The only other submission to the NBRC, from Ruby Lake NWR in Elko County (2011-089), was not endorsed because of questionable origin (Meyers 2014). In California, this species began to colonize along the Colorado River in the 1940's, and some birds

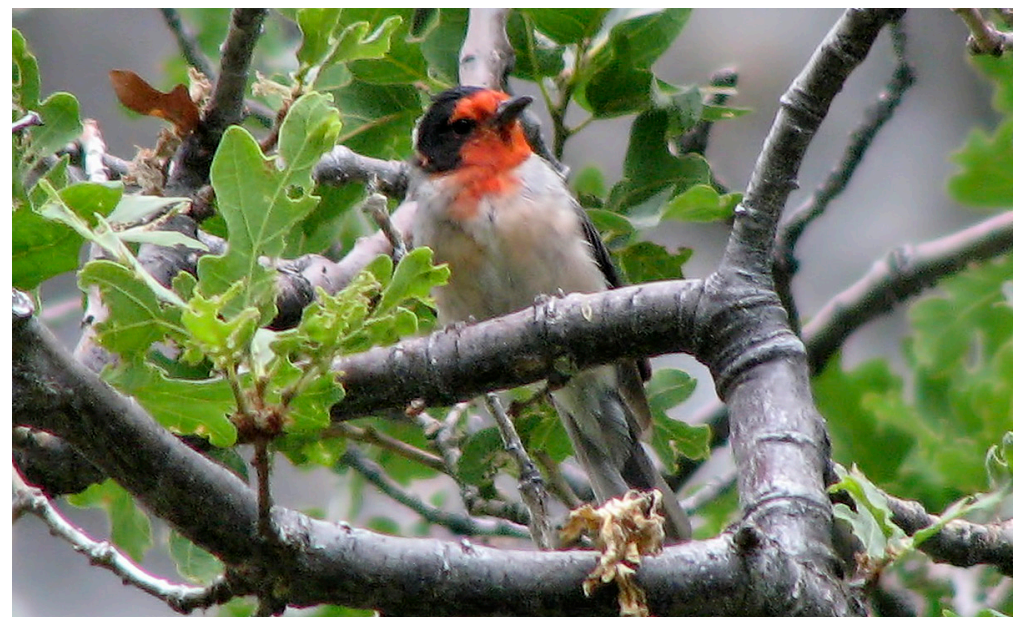

Figure 11. All three NBRC-endorsed records of the Red-faced Warbler are from the Fletcher Canyon trail in the Kyle Canyon section of the Spring Mountains National Recreation Area. All are summer records, in 2007, 2009, and this one, 29 June-3 August 2013. The habitat in this area is suitable for the Red-faced Warbler, and access is easy, attracting birders regularly. There are several reports from other locations in the Spring Mountains, all for early September 1974 (Alcorn 1988), but the NBRC has been unable to find reviewable documentation of them.

Photo by Andrew Lee 


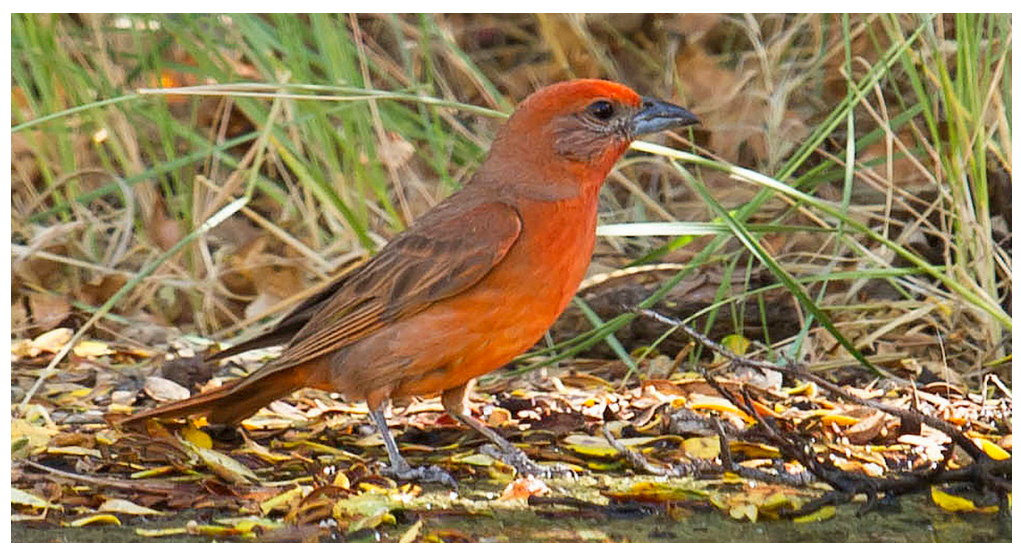

Figure 12. The NBRC has endorsed only two records of the Hepatic Tanager, a species that has been inferred, by extrapolation from three records of single birds (Johnson 1965), to breed regularly in the mountains of southern Nevada. Given the remoteness of some of the suitable habitat, that assumption may be correct, but this adult male at an easily accessible campground on Mt. Charleston, Clark Co., from at least 4 to 24 July 2014, is the first recorded in the Spring Mountains and the first in any of southern Nevada's mountains since 1963.

Photo by Bernadine Murray

found at desert oases away from the river "may represent legitimate, wild, wandering birds" (Hamilton et al. 2007). However, the resident population along the river is now probably extirpated. Dunn and Alderfer (2011) wrote, "formerly a few ... to Colorado River in southeastern CA."

PYRRHULOXIA Cardinalis sinuatus (2, 1). 2014-033, Corn Creek (Clark), 15 May 1993. R. Rucker. Adult female, according to the thorough and careful written documentation. The timing of this late spring record fits with the Pyrrhuloxia's pattern in the California desert, where seven CBRC-endorsed records (comprising 13 individuals) are from late spring and early summer (with one of those birds remaining into mid-summer.) There are also two records from that region for winter, one for fall, and three for mid-summer (Hamilton et al. 2007, http://www.californiabirds. org/cbrc_book/update.pdf ). Nevada's only other record (2009-018) is from 15 December 1979 (Meyers 2010).

PAINTED BUNTING Passerina ciris (10, 1). 2013-111, McCarren Ranch (Storey), 13-14 Sep 2013. G. Scyphers (P); R. Lowry (P). The first record from northern Nevada. This individual was in female/immature plumage, as were eight of Nevada's nine previous Painted Buntings. For more information on this species in Nevada, see Meyers (2015).

DICKCISSEL Spiza americana (7, 1). 2014-014, Veterans Memorial Park, Hawthorne (Mineral), 15 May 2014. G. Scyphers. Male. Nevada's third spring record (one in April, two in May). The four other records are from September.

BRONZED COWBIRD Molothrus aeneus (4, 1). 2013-116, Corn Creek (Clark), 21 May 2013. G. Scyphers (P). Adult male. All four NBRC-endorsed records involve birds found in spring in southern Nevada (Clark and Nye counties.)

ORCHARD ORIOLE Icterus spurius (9, 1). 2014-047, Corn Creek (Clark), 15 Jul 
2014. M. Swink (P). Adult male. Perhaps a fall migrant, as "after nesting, Orchard Orioles, particularly males, leave the breeding grounds early" (Jaramillo and Burke 1999).

BALTIMORE ORIOLE Icterus galbula $(8,3)$. 2013-105, Pahranagat NWR (Lincoln), 19 May 2013; found by Dave McNinch. G. Scyphers (P). Adult male.

2014-016, Overton (Clark), 25 May 2014. A. Lee (P). Adult male.

2014-019, Pahranagat NWR (Lincoln), 25 May 2014. D. Serdehely. Adult male.

\section{CORRIGENDA}

The introduction to the 2013 annual report (Meyers 2015) stated, "the committee began reviewing pre-committee records in 2007. Since that time, we have reviewed 93 such records, of which 86 have been endorsed." Those totals were incorrect. The second sentence should have read, "since that time, we have reviewed 97 such records, of which 89 have been endorsed."

\section{ACKNOWLEDGMENTS}

The NBRC thanks everyone who contributed to the accounts contained in this report. All submissions, photos, advice, comments, and opinions are greatly appreciated. We apologize to anyone who may have been overlooked. Some of the contributors on this list are no longer with us, but their contributions are no less appreciated: Tim Almond, Aaron Ambos, John Anderson, Meg Andrews, James Bailey, Rod Bailey, Jennifer Ballard, Scott Barnes, Jim Boone, Renée Bourgea, Carl Bullock, Samantha Burrell, Marissa Buschow, G. Scott Clemson, Marian Cressman, Dave DesMarais, Ken Drozd, Karole and Norm Finklestein, Shawneen Finnegan, Rick Fridell, Dennis Ghiglieri, Craig Grant, Leonard Hoskins, Eric Hough, Theresa Hyde, John Icenogle, Mark Kasprzyk, Charles S. Lawson, Andrew Lee, Paul E. Lehman, Tim Lenz, Rob Lowry, Neil McDonal, Martin Meyers, Randall Michal, Kathy Molina,Vincent Mowbray, Bernadine Murray, Greg and Pam Nelson, Christina Nycek, Nathaniel Nye, Zachary Ormsby, Anne Pellegrini, William Prange, John C. Ruckdeschel, Robert Rucker, Mike San Miguel, Greg Scyphers, Dennis Serdehely, Archie Slater, Justin Streit, Jesse Swift, Mike Swink, Jane Thompson, Jeanne Tinsman, Carolyn Titus, Adriaan Joseph van Rossem, David Vander Pluym, Deb Vogt, Jack Walters, and Fred Welden.

Committee members Jeanne Tinsman, Greg Scyphers, and Carl Lundblad reviewed the report and provided helpful suggestions. Outside review was provided by Daniel D. Gibson, Paul E. Lehman and Jon L. Dunn. Special thanks to Western Field Ornithologists and Great Basin Bird Observatory for their support and encouragement.

\section{LITERATURE CITED}

Alcorn, J. R. 1988. The Birds of Nevada. Fairview West Publ., Fallon, NV.

Austin, G. T., and Bradley, W. G. 1971. The avifauna of Clark County, Nevada. J. Ariz. Acad. Sci. 6:283-303; doi 10.2307/40022840.

Cochran, J. 2006. Report of the Nevada Bird Records Committee for 2005. Great Basin Birds 8:55-61.

Corman, T., and Wise-Gervais, C. (eds.) 2005. Arizona Breeding Bird Atlas. Univ. of New Mexico Press, Albuquerque.

Cressman, J., Baepler, D., Biale, A., Crow, D., Hoskins, L., Neel, L., Ryser, F., and Eidel, J. 1998. Initial report of the Nevada Bird Records Committee: 1994-1996 records. Great Basin Birds 1:63-67.

Dunn, J. L., and Alderfer, J. 2011. National Geographic Field Guide to the Birds of North America. Natl. Geogr. Soc., Washington, D.C. 
Dunn, J. L., and Garrett, K. L. 1997. Field Guide to Warblers of North America. Houghton Mifflin, Boston.

Floyd, T., Elphick, C. S., Chisholm, G., Mack, K., Elston, R. G., Ammon, E. M., and Boone, J. D. 2007. Atlas of the Breeding Birds of Nevada. Univ. of Nev. Press, Reno.

Gross, A. O. 1931. Snowy Owl migration 1930-1931. Auk 48:501-511; doi 10.2307/4076254.

Hamilton, R. A., Patten, M. A., and Erickson, R. A. (eds.) 2007. Rare Birds of California. W. Field Ornithol., Camarillo, CA.

Jaramillo, A. and Burke, P. 1999. New World Blackbirds, the Icterids. Christopher Helm, London.

Johnson, N. K. 1965. The breeding avifaunas of the Sheep and Spring ranges in southern Nevada. Condor 67:93-124; doi 10.2307/1365256.

Lawson, C. S. 1973a. Notes on Pelecaniformes in Nevada. W. Birds 4:22-30.

Lawson, C. S. 1973b. Charadriiformes new to Nevada. W. Birds 4:77-82.

Lawson, C. S. 1977. Nonpasserine species new or unusual to Nevada. W. Birds 8:73-90.

Linsdale, J. M. 1936. The birds of Nevada. Pac. Coast Avifauna 23.

McCaskie, G., and Garrett, K. 2014. Southern California. N. Am. Birds 67:518-519.

Meyers, M. 2008. 2007 Nevada Bird Records Committee report. Great Basin Birds 10:36-62.

Meyers, M. 2010. 2008/2009 Nevada Bird Records Committee report; www.gbbo. org/nbrc/GBB_2008_2009_Report.pdf.

Meyers, M. 2013. 2011 Nevada Bird Records Committee report. W. Birds 44:17-32.

Meyers, M. 2014. 2012 Nevada Bird Records Committee report. W. Birds 45:2-17.

Meyers, M. 2015. 2013 Nevada Bird Records Committee report. W. Birds 46:2-27.

Patten, M. A., and Erickson, R. A. 2000. Population fluctuations of the Harris's Hawk (Parabuteo unicinctus) and its reappearance in California. J. Raptor Res. 34:187-195.

Patten, M. A., McCaskie, G, and Unitt, P. 2003. Birds of the Salton Sea: Status, Biogeography, and Ecology. Univ. of Calif. Press, Berkeley.

Rosenberg, G. H., Radamaker, K., and Stevenson, M. M. 2011. Arizona Bird Committee report, 2005-2009 records. W. Birds 42:198-232.

Rottenborn, S. C., and Morlan, J. 2000. Report of the California Bird Records Committee: 1997 records. W. Birds 31:1-37.

Titus, C. K. 1996. Field List of the Birds of Nevada. Red Rock Audubon Soc., Las Vegas, NV.

Unitt, P. 2004. San Diego County bird atlas. Proc. San Diego Soc. Nat. Hist. 39.

Accepted 6 November 2015 